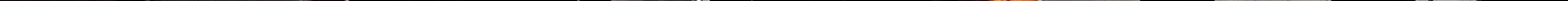




\title{
El Centro Histórico de Quito y sus múltiples formas de concebirlo durante la década de 1980
}

\author{
The Historic Centre of Quito and its multiple ways of conceiving it during the 1980s
}

\author{
Raúl Zhingre \\ Escuela Politécnica Nacional, Quito, Ecuador \\ raulgzc@yahoo.es \\ https://orcid.org/0000-0002-4835-6810
}

\section{Resumen}

El presente trabajo sostiene que no hay un solo Centro Histórico de Quito (CHQ), sino múltiples formas de concebirlo y representarlo. Conforme a lo anotado, este artículo plantea analizar al CHQ en el marco de dos distintos enfoques durante la década de 1980. Uno de estos es aquel que propone la exaltación del paradigma arquitectónico monumental que convierte al monumento en una cosa a conservar, en lugar de apreciarlo como un espacio de significados culturales. Y, el otro corresponde a la propuesta de ciudad y centro histórico como diversidad, lo cual implicaba criticar el enfoque arquitectónico que ignoraba los factores sociales, económicos y culturales.

\section{Abstract}

This work maintains that there is not a single Historic Center of Quito (HCQ), but multiple ways of conceiving and representing it. According to the annotated, this article proposes to analyze the HCQ in the context of two different approaches during the 1980s. One of these is the one that proposes the exaltation of the monumental architectural paradigm that makes the monument a thing to be conserved, instead of appreciating it as a space of cultural meanings. And, the other corresponds to the proposal of city and historical center as diversity, which implied criticizing the architectural approach that ignored social, economic and cultural factors. It is evident because of the research that these two ways 
Se evidencia como resultado de la investigación que estas dos formas de concebir al CHQ, no solo que abordaron el patrimonio de forma polarizada, sino que además se convirtieron en un escenario desde el cual problematizaron la identidad del Ecuador.

Palabras clave: Centro Histórico de Quito; patrimonio; monumentalismo; diversidad. of conceiving the HCQ, not only that they addressed heritage in a polarized way, but also became a scenario from which they problematized the identity of Ecuador. Keywords: Historic Center of Quito; heritage; monumentalism; diversity.

El trabajo que expone esta investigación contiene tres partes: la primera examina el marco histórico del CHQ para identificar los principales procesos de constitución y desarrollo y destacar sus rasgos más característicos con la finalidad de encontrar el contexto global del tema propuesto en este análisis; la segunda analiza las dos concepciones sobre el CHQ, y finaliza con las conclusiones.

\section{Marco contextual del Centro Histórico de Quito}

El ejercicio de revisión histórica sobre el CHQ y la historia urbana, en el Ecuador, tiene una tradición de varias décadas. Como consecuencia de esa revisión, entre 1895 y 2000, se puede distinguir cinco períodos como claves de lectura. Quedando pendiente consensuar un sexto período que corresponde al siglo XXI, relacionando con la globalización.

La constitución y desarrollo del actual CHQy su periferia inmediata, vista en su descripción formal, en términos de límites, constituye una matriz común que, en los cinco períodos siguió una ruta de alrededor de un siglo, cuyos

"límites identifican dos áreas muy visibles: un área de protección edificada (376 ha.) y otra de protección natural (230 ha.).

La zona se articula alrededor de un núcleo central (54 ha. aprox.) que corresponde al de la parroquia González Suárez (55 manzanas) y el área circundante se integra, a su vez, con los barrios [que corresponde al área periférica constituida por 14 unidades que según la UNESCO forman parte de la declaratoria de Quito Patrimonio de la Humanidad. Los barrios en mención son]: la Alameda, San Blas, San Juan, El Tejar, San Roque, La Chilena, El Placer, Aguarico, San Diego, San Sebastián, La Recoleta, La Loma, San Marcos y La Tola (que comprenden 229 manzanas).

En cambio, el área de protección natural corresponde a las laderas de las elevaciones [naturales y lugares sagrados incas] Panecillo, Itchimbia, El Placer, además de uno de los flancos de quebrada del rio Machángara, como áreas de amortiguamiento natural'.

\section{La configuración del área principal (1895-1910)}

Este primer período comprende la "configuración del área matriz del CHQ”, es decir la delimitación histórico-geográfica que se define en la coyuntura de la Revolución Liberal (1895-1910) ${ }^{2}$, caracterizada por un

\footnotetext{
1. (MDMQ, Dirección General de Planificación y Junta de Andalucía, 2003), en CABRERA HANNA, Jaime Santiago, "El Centro Histórico de Quito en la planificación urbana (1942-1992). Discursos patrimoniales, cambios espaciales y desplazamientos socioculturales", Territorios, n. ${ }^{\circ} 36,2017$, pág. 192.

2. La Revolución Liberal fue un proceso de profundas trasformaciones políticas y económicas. Dos de estas corresponde al inicio de las relaciones
} 
contexto de dominio de las relaciones capitalistas de producción en el Ecuador que, explica la modificación sustancial del proceso urbano de las ciudades más importantes del Ecuador como son Quito y Guayaquil.

Dos sujetos van a actuar conforme al área matriz del CHQ y al contexto: la modernización de los terratenientes agrarios a través de su conversión en terratenientes urbanos y, la consecuente urbanización del Municipio de Quito, en tanto dirige su actividad fundamental hacia las zonas donde esa nueva fracción de la clase terrateniente tiene sus intereses.

Por último, en este período de constitución del área matriz se configura la diferenciación entre centro histórico y ciudad, la cual estuvo atravesada por un doble proceso. Una densificación extrema de la ciudad que establece los límites de lo que hoy se conoce como CHQ. Y, una expansión de la ciudad que conlleva el desborde de lo que, hasta entonces, fueron las barrearas naturales de la ciudad: el Panecillo por el sur y el parque de la Alameda por el norte 3 .

\section{El Centro Histórico y la definición como problema (1930-40)}

El segundo período del CHQ corresponde a los años 30 e inicios del 40. La crisis del modelo agroexportador de las clases dominantes y su consecuente impacto en la urbanización del Ecuador es un rasgo característico del contexto. Como resultado de ello se produce un intenso flujo migratorio a Guayaquil y Quito, ocasionado por la expulsión de la población agraria campesina ubicadas en las zonas en crisis, de la Región Sierra y Costa.

El flujo migratorio sobre Quito va a incidir en la composición social de esta ciudad, manifestándose en la configuración de tugurios, a partir de esto, se redefine el área matriz del anterior período, ya no solo por su riqueza y valor histórico de la clase pudiente, sino también por la concentración de la pobreza social de migrantes. La magnitud de la situación convertirá al CHQ en problema a debatir.

Asumiendo este desafío, entre 1942-1944, se produce la primera planificación racional de la ciudad por parte del Municipio de Quito a través de la formulación del Plan Regulador, elaborado por el uruguayo, Jones Odriozola, que propone pensar la ciudad de forma global ${ }^{4}$. A la vez, lleva consigo, según, la opinión de algunos analistas sobre el Plan "la imaginación del "espacio colonial como lugar esencial de Quito que brotaba de una explicación nutrida por la ideología del hispanismo"s.

El reto de pensar al CHQ en su escala colonial, la necesidad de planificar la ciudad desde el punto de vista jerarquizado, les llevó a los creadores del Plan a buscar lecturas que contraponía teóricamente a Quito como ciudad milenaria, diversa y plural, que junto con la ideología hispanista que reforzó el enfoque de solo conservar monumentos "en la actualidad aún funciona como potente marca social".

capitalistas en el Ecuador y la separación de la Iglesia del Estado. Su dirigente fue Eloy Alfaro.

3. CARRIÓN MENA, Fernando, "Centro Histórico de Quito: notas para el desarrollo de una política urbana alternativa", PERALTA, Evelia; GONZÁLEZ

TAMARIT, Luis; CARRIÓN MENA, Fernando y ROMÁN RUÍZ, José (coords.), Centro Histórico de Quito, problemas y perspectivas, Serie Quito 1, Quito, Ilustre Municipio de Quito, 1990, págs. 17-18.

4. CARRIÓN MENA, Fernando, "Centro Histórico de Quito: notas...", op. cit., págs.18-20.

5. CABRERA HANNA, Jaime Santiago, "El Centro Histórico de Quito en...", op. cit., pág. 197.

6. Ibídem. 


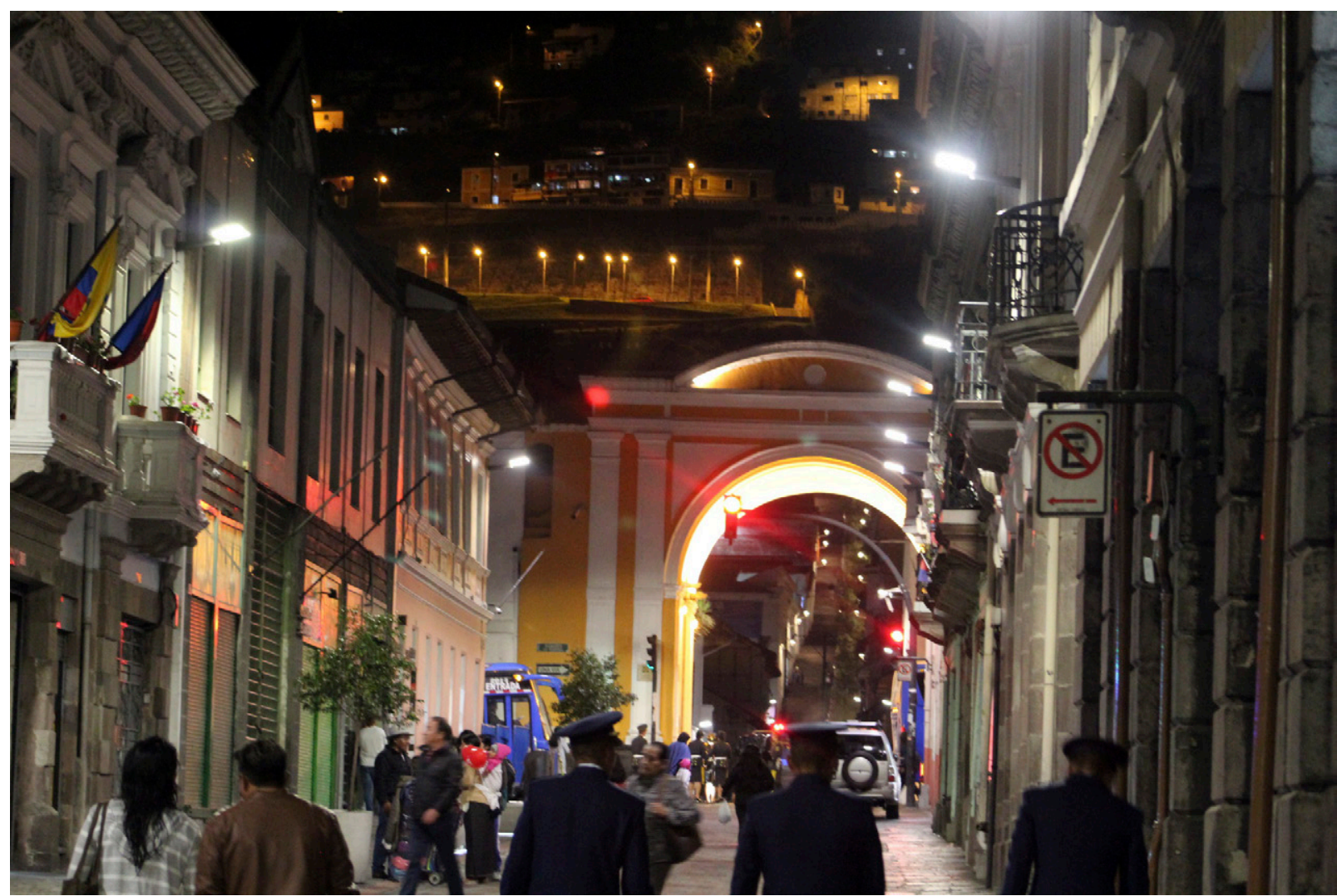

Fig. 2. Arco de la Reina. Centro Histórico de Quito. Foto: Raúl Zhingre (Junio de 2017).

En tanto el Plan atendió a la política oficial, identificó tres zonas con criterios de "segregación espacial socioeconómica y habitacional: la Sur, con actividades fabriles, industriales y espacios para la vivienda de obreros y trabajadores; el Centro, que se extiende desde la ciudad colonial al centro de gobierno con las actividades burocráticas, decisorias de la vida politica, servicios, comercios y la población urbana inmiscuida en dichas actividades y, finalmente, el Norte, que acogería los equipamientos de recreación, de educación y a las clases sociales más acomodadas".

En estas zonas, se propuso la formación de nueve centros funcionales, entre ellos, el Religioso y el Histórico, que corresponderían al centro de la ciudad. Así, el estudio de esta periodización, sienta las bases para la diferencia entre centro histórico y centro urbano.

\section{La distinción entre centro histórico y centro urbano (1960-70)}

Este período corresponde a los ańos 60 y 70, y atiende a la diferencia entre centro urbano y centro histórico, como consecuencia de los tardíos procesos de modernización capitalista que vive el país, lo cual fue una ventaja, pues ello permitió mantener el CHQ con vida y en condiciones aceptables, en comparación a otros centros históricos latinoamericanos ${ }^{8}$.

7. Ibídem, pág. 195.

8. CARRIÓN MENA, Fernando, "Centro Histórico de Quito: notas...", op. cit., pág. 20. 
Además, esta diferenciación fue producto de la crisis de centralidad urbana, en términos de su funcionalidad, pues, en los años 60 y 70 comienza un nuevo proceso: la descentralización de las actividades urbanas del CHQ hacia la zona de la Mariscal Sucre, localizada al norte de la urbe, a donde se trasladan actividades comerciales, bancarias y tecnocráticas. La Mariscal se convierte también en zona residencial de sectores medios altos.

Esta descentralización de las funciones urbanas generó nuevas líneas de conflictos al configurarse, por primera vez, la distinción entre centro histórico y centro urbano. Este último correspondería a la Mariscal, como un nuevo polo comercial y financiero, y el primero al actual CHQ, con lo cual, "se consolidó la idea de "centro histórico" como "unidad constitutiva" e "independiente del resto de la ciudad, merecedora de atención especial en cuanto a su conservación, inversión y financiamiento".

Lo que conduce a la definición de una nueva problemática urbana entre centro histórico y barrios periféricos. La problemática permitió al Municipio reconocer al CHQ como un campo que debe ser enfrentado desde la planificación, surgiendo así, el Plan Municipal (1967) y el Plan Director (1973).

Este último Plan "trazó un paisaje urbano que reprodujo los modelos funcionales y segregativos espaciales y económicos de los cincuenta" dando prioridad al turismo monumental del CHQ en su conjunto. "De esta manera, el uso del espacio [...] tuvo, entre los sesenta y setenta, una fisonomia marcadamente comercial que desembocó en un paulatino cambio de los patrones de habitabilidad de los entornos patrimoniales" ${ }^{10}$.

\section{Centro Histórico y su crisis (1980)}

El cuarto período se inicia a mediados de los años 70, (en el anterior período) en un contexto de auge petrolero, dirigido por las dictaduras militares. Bajo ese influjo y en un contexto excepcional, Quito sufre un profundo impacto, pues esta ciudad recibe altos rubros para financiar la modernización física de carreteras que producen fisuras al interior del $\mathrm{CHQ}^{11}$.

La modernización que tenía un anclaje en lo físico monumental, genera un violento proceso de expulsión de la población tugurizada hacia los extremos de Quito, dando lugar, a la creación de barrios periféricos y a la agudización de los existentes como aquellos del CHQ.

La fragmentación que produce la modernización y la descentralización de ciertas funciones urbanas, que iniciaron en el período anterior, está basada en unas nuevas tensiones entre centro y periferia. Una de estas, es aquella que coloca al CHQ, al finalizar los años 70, como un centro popular y político en decadencia.

A consecuencia de ello empezó el proceso de vaciamiento y abandono de las actividades residenciales y administrativas, sobre todo privadas, en el CHQ, situación que se completó con el desplazamiento paulatino de las entidades de decisión económica y las sedes bancarias al norte de la ciudad. Esto fue generando el decaimiento del Centro Histórico en lo patrimonial, político, cultural, económico y administrativo.

9. Ibídem, págs. 198, 200.

10. Ibídem, pág. 200.

11. Ibídem, pág. 22. 
En este período, se producen algunos hechos que modificaron la reflexión del CHQ: la declaratoria de Quito como Patrimonio Cultural de la Humanidad, hecho que tuvo lugar en 1978, por parte de la UNESCO, la crisis económica y la incapacidad de gestión de la municipalidad durante la década de 1980, y, el terremoto de 1987, que se presenta como indicador que marca la crisis del CHQ en los 80. Así, de los hechos citados de esta época hay que retener algunas características que podemos reagrupar en torno a la idea de crisis.

De acuerdo a lo anterior, el contexto en que surgen las discusiones sobre el CHQ, y que se relaciona con el arco temporal de nuestro tema investigativo, está caracterizado por la usencia de un proceso sistemático sobre política urbana que estaba en concordancia con el débil rol del Municipio de Quito para pensar el crecimiento de Quito y las medidas de planificación y ordenamiento, y así administrar temas públicos referidos a trasporte, servicios básicos, patrimonio, turismo, migración interna, comercio callejero, etc.

Además, la crisis nacional a causa de la implementación del modelo neoliberal y la falta de presupuesto económico dio como resultado una crisis urbana y de legitimidad del municipio.

En el contexto de crisis en que vivía el Ecuador y la acelerada dinámica de urbanización nacional llevó a que, la política urbana y las problemáticas del CHQ sea un problema coyuntural que sigue una línea de solución técnica que desconoce los conflictos sociales, económicos e históricos.

Además, la declaratoria como Quito Patrimonio de la Humanidad no fue analizada por parte de las autoridades patrimoniales y municipales como un valor agregado al mejoramiento de las condiciones de vida de sus habitantes más empobrecidos del CHQ. Esto porque "se trató de una propuesta externa que no tuvo contraparte en una politica interna"12.

El galardón otorgado por la UNESCO fue usado para promocionar, regular y controlar el uso comercial del CHQ "como conjunto monumental elevado a estatus de patrimonio cultural de la humanidad"13, con fines turísticos que beneficiaron a los grandes capitales de hoteles, teatros, salas de juegos, cadenas de restaurantes, etc.

A partir de esto, por ejemplo, la Empresa de Teatros y Hoteles de Quito C.A. tomó impulso económico, la misma que había sido fundada por los empresarios privados, César y Carlos Mantilla Jácome, en 1945, y conformada por varios hoteles y teatros cinematógrafos, entre ellos, los Teatros Bolívar, Variedades, Cumandá, Puerta del Sol y Alameda. Inmuebles ubicados dentro de la zona central del CHQ. En cuanto a los hoteles que formaban parte de la Empresa y que se beneficiaron del turismo fueron: Hotel Colonial, Crillón, Royal y Columbus ${ }^{14}$.

Por otro lado, desde una perspectiva hispanista llevada a cabo por el Municipio quiteño y otros agentes, la declaratoria presentaba al Quito histórico como un proceso que articulaba la identidad del país, desde la riqueza histórica de los monumentos coloniales, obscureciendo, entre otros aspectos, el legado aborigen y republicano que le componía.

12. CARRIÓN MENA, Fernando, "Centro Histórico de Quito: notas...", op. cit., pág. 22.

13. CABRERA HANNA, Jaime Santiago, "El Centro Histórico de...", op. cit., págs. 209-211.

14. Fundación Teatro Bolívar, "Teatro Bolívar desde su inauguración en 1933 ha sido escenario de producciones más emblemática del arte musical y teatral". Recuperado de: http://www.teatrobolivar.org/sobre.html (consultado el 10 de enero 2018). 


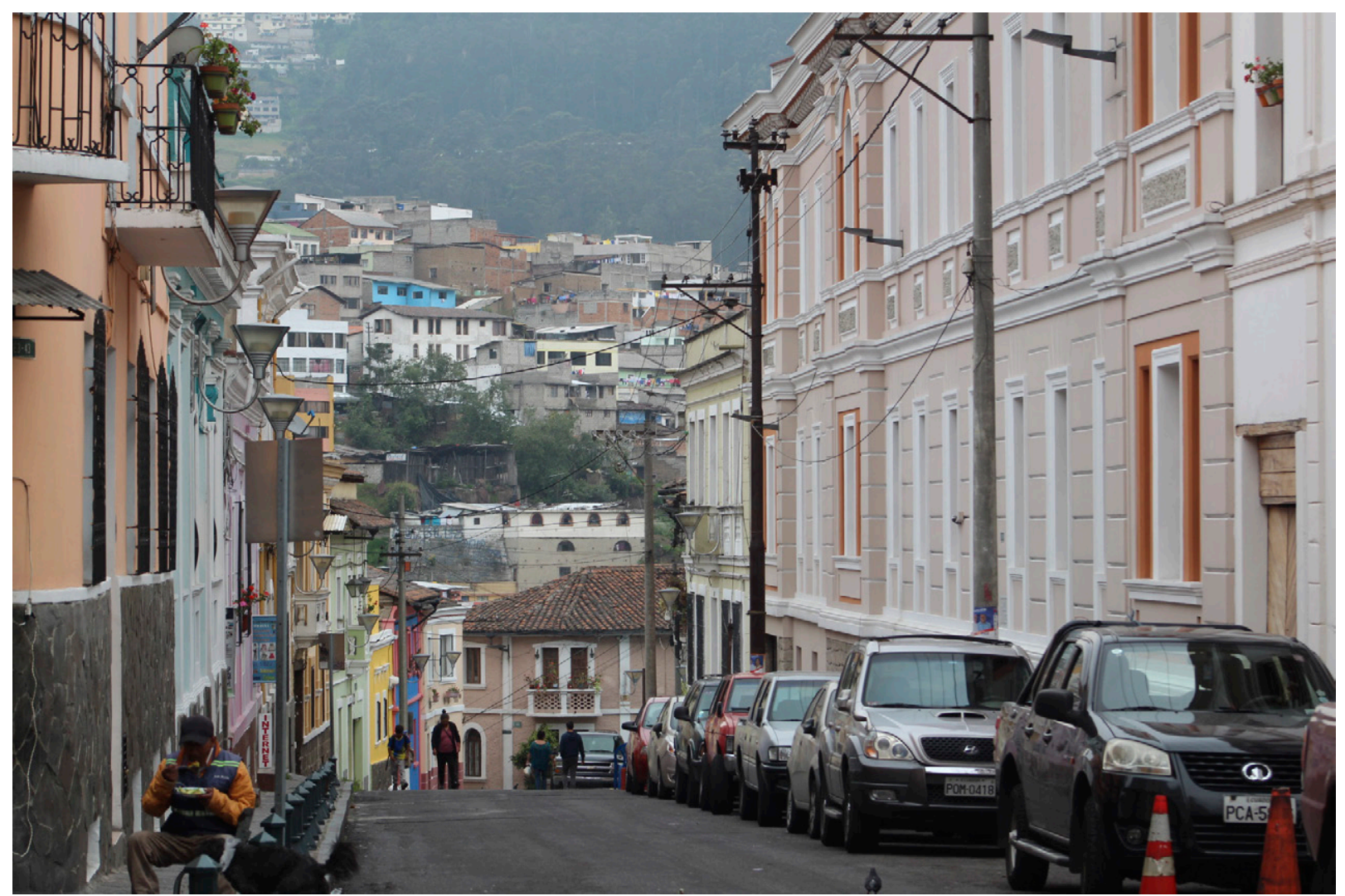

Fig. 3. Calle Flores. Centro Histórico de Quito. Foto: Raúl Zhingre (Junio de 2017).

Fue luego del terremoto de 1987, siniestro que afectó las estructuras monumentales de la zona del CHQ, que se dio una modificación sustancial en la perspectiva de poner en interrogante la historia, los procesos de gestión territorial y urbanístico del CHQ, así como los intereses políticos e ideológicos subyacentes, se apeló a una reconstrucción histórica y social de la ciudad, en la cual prima el acento en la comprensión del patrimonio como una construcción de carácter histórico y social. Desde esta perspectiva se abordaron temas sobre la migración interna, la tugurización del CHQ, las modificaciones en los patrones de la economía local, las actividades comerciales y de sustento de la población, así como las distintas formas de habitar la ciudad, el Centro Histórico y sus barrios, entre otros aspectos ${ }^{15}$. Esta importante reflexión se dio de forma incompleta, quedando pendiente el análisis sobre las concepciones del Centro Histórico, en clave histórica, que es lo que analiza este trabajo.

\section{Centro Histórico entre dimensiones sociales y monumentales (1990-2000)}

El período del CHQ y su crisis de los 80 concluyen con la quiebra económica de los años 90, cuyo punto más crítico del contexto fue el llamado Feriado Bancario de 1999 y la migración forzosa que la debacle financiera trajo consigo. Ambos factores contribuyeron al auge de formas de economía doméstica basadas

15. CABRERA HANNA, Jaime Santiago, Propuesta Investigación sobre dinámicas socio espaciales, memoria socio histórica y patrimonio cultural, Centro Histórico y parroquias del DMQ, (presentado al Instituto de Patrimonio de Patrimonio- IMP), Quito, documento inédito, 23 de enero, 2015, pág. 8 . 
en emprendimientos no formales y en la diversificación de actividades dedicadas a la promoción de servicios de bajo costo. Esto produjo cambios en el uso de las edificaciones de las zonas patrimoniales y la forma de comprender socialmente al CHQ.

De acuerdo con este contexto, el quinto período del CHQ, le corresponde a los años noventa y dos mil, en el que destaca visos de incorporación de dimensiones sociales culturales de la ciudad y de su CHQ, pero supeditado al paradigma monumental y conservacionista, como factores concluyentes de la planificación de Quito, que puso en marcha acciones orientadas a segregar las actividades informales.

En ese período, finamente, se estimuló también la conformación de todo un campo técnico y profesional especializado y de ayudas de organismo internacionales, como la Junta de Andalucía, que fue de la mano de la consolidación del campo profesional de la historia como disciplina ${ }^{16}$.

Expuesto lo precedente, podemos analizar las dos concepciones que a nuestro parecer, parecen resumir la visión que se manifiesta durante estos años sobre el CHQ.

\section{Concepciones sobre el Centro Histórico de Quito}

\section{El monumentalismo como paradigma del centro histórico}

Debido al terremoto que se dio en el Ecuador, en 1987, el período entre 1987 y 1992 "fue un momento de crisis patrimonial, en el sentido de la propia destrucción del patrimonio edificado, que colocó elementos clave de la gestión del patrimonio de la ciudad en términos de su vulnerabilidad"17.

En este contexto, es importante pensar cómo la ciudad y la gestión del municipio encararon al patr imonio edificado y a la inversión de recursos que vino luego del sismo. Fue un tiempo de conformación de la estructura de financiamiento y manejo del patrimonio de la ciudad, expresado en el Fondo de Salvamento, creado mediante Ley No 82 (1987) y con el apoyo de la Junta de Andalucía de Espańa. Si bien hubo una preocupación social sobre el patrimonio, que se manifestó mediante discusiones sobre temas sociales y la propia configuración del CHQ como espacio habitado, finalmente se consagró una visión monumentalista, en la planificación urbana de Quito ${ }^{18}$.

Estas consideraciones hallan su confirmación en el objeto del monumentalismo que en los años 80 estaba en el estudio de la rehabilitación, restauración y conservación del Centro Histórico con base en lo físicoespacial. Desde esta perspectiva, el Municipio de Quito afirmó una visión de planificación física de monumentos mediante políticas que expresaban una concepción técnica y monumental sobre el centro de la ciudad.

Este fenómeno puede graficarse, entre otros casos, mediante una nota publicada en El Comercio de 1988, en donde voces críticas a esta visión acotaban que la mirada técnica y monumental tenía como

16. CABRERA HANNA, Jaime Santiago, "El Centro Histórico de..." op. cit., págs. 209-212.

17. CABRERA HANNA, Jaime Santiago, "Los orígenes del discurso patrimonial autorizado en la planificación urbana de Quito", Simposio de Historia Urbana, IX Congreso Ecuatoriano de Historia 2015, Quito, 15 de julio de 2015.

18. CABRERA HANNA, Jaime Santiago, "Los orígenes del discurso...", op. cit. 
marcos de actuación "la falta de personal especializado dentro de la municipalidad; la visión desmedidamente conservacionista y estática de las politicas y ordenanzas; y su carácter negativo, prohibitivo y punitivo que, en lugar de promover la conservación y rehabilitación con participación de todos los agentes sociales involucrados, tuvo como consecuencia la agudización del deterioro y la precariedad del patrimonio urbano y arquitectónico. A todo esto se sumaban los intereses económicos particulares de algunos propietarios" ${ }^{19}$.

De lo anterior, se puede señalar que el problema central no fue el monumentalismo como tal, sino el peso físico-espacial que se le dio frente a otras dimensiones sociales, culturales e históricas del manejo del área histórica del CHQ. Por ello, el cuestionamiento al paradigma estuvo dirigido a su visión cosificada del patrimonio como un "objeto" o "sitio", que tomó distancia del patrimonio como significado y creación de memoria diversa ${ }^{20}$.

Este modelo monumentalista privilegió lo físico-espacial a través de cuatro elementos: la consideración de monumentos arquitectónicos religiosos y civiles; una visión de lo monumental dentro de un entorno urbano exterior; el reconocimiento de una estructura urbana como monumento; y, la incorporación de monumentos coloniales y republicanos ${ }^{21}$.

Debido a esta concepción, en el Ecuador, no se implementó ley alguna sobre conservación en el CHQ que tomara en cuenta, la cotidianidad y las problemáticas de los barrios periféricos cercanos al centro patrimonializado, haciéndolos partícipes de los propósitos de la conservación y los fundamentos de la gestión de los legados con valor histórico 22 .

Sobre esta base, este enfoque monumental se reflejó en la Declaratoria de Quito Patrimonio Cultural de la Humanidad, hecho que tuvo lugar en 1978, bajo la coordinación de la UNESCO, donde se relevaba la importancia de esta ciudad como estructura patrimonial colonial, por ello, hubo una mayor valoración patrimonial del CHQ respecto de sus monumentos arquitectónicos y artísticos pertenecientes a esta época.

Conforme a este argumento, la Declaratoria presenta al Quito histórico como un proceso que articula la identidad del Ecuador desde el punto de vista colonial. De ahí que como lo prueban las fuentes de información, en 1984, se sostenía que Quito, "siempre ha constituido el origen más remoto de la nacionalidad ecuatoriana” ${ }^{23}$, con el propósito de argumentar que esta ciudad tenía un solo centro histórico y que éste nace en el momento y lugar fundacional de la ciudad, con lo cual, por un lado, la historia de la ciudad comienza y termina en la época colonial, congelándose en su origen, y por otro, concibiendo que los cambios urbanos se producen por fuera de la zona considerada histórica ${ }^{24}$. Así pues, se proponía conservar y proteger al CHQ como parte viva de la ciudad.

19. ORTIZ CRESPO, Alfonso, "La conservación de los centros históricos: ¿una utopía?", Diario Hoy (Quito), 17 de enero, 1988, 6-C. 20. SMITH, Laurajane, "El 'espejo patrimonial' ¿llusión narcisista o reflexiones múltiples?, Revista Antípoda, n.` 12, 2011, pág. 44.

21. CARRIÓN MENA, Fernando, "Centro Histórico de Quito...", op. cit., pág. 24.

22. Al respecto véase BALLART HERNÁNDEZ, Josep y I TRESSERAS, Jordi Juan, Gestión del patrimonio cultural, Barcelona, Planeta, 2010.

23. VILLASÍS, Carlos, "Declaratoria de Quito", Declarar el Centro Histórico de la ciudad de Quito "Patrimonio cultural del Estado", Instituto de Patrimonio Cultural del Ecuador, Quito, diciembre de 1984, pág.1.

24. CARRIÓN MENA, Fernando, El laberinto de las centralidades históricas en América Latina: el centro histórico como objeto del deseo, Quito, Ministerio de Cultura del Ecuador, 2010, pág. 68. 
Complementaría la reflexión a este propósito, cuando la Declaratoria consagraba el elemento de la monumentalidad colonial como criterio universal de valoración, lo que condicionaba la naturaleza del patrimonio en Quito ${ }^{25}$.

De ello se puede concluir que el monumentalismo, en los años 80, tenía como propósito conservar monumentos o conjuntos monumentales, sobre todo arquitectónicos y religiosos, pues se pensaba que la arquitectura del CHQ era un lugar donde se podía representar la nación y un lugar a partir del cual consolidar narrativas de la historia y la memoria nacional.

Por ello, el CHQ, en la mayor parte de la década de nuestro estudio, emerge a través de una de sus identidades: la monumental-colonial: se trataba de encontrar la huella de Espańa en Quito. Esta forma de comprender al CHQ dejó resultados positivos para sus impulsores, entre ellos, los operadores turísticos, los alcaldes, la Cámaras de Comercio, la prensa como El Comercio y Últimas Noticias, la Policía Metropolitana de Quito, personeros oficiales, que habían apoyado la Declaratoria de la UNESCO como Rodrigo Pallares, Director Nacional de Patrimonio Artístico de aquel entonces ${ }^{26}$, quienes centraron la atención en templos religiosos y en monumentos o conjuntos arquitectónicos para convertir al CHQ en "relicario de arte colonial de América".

De esta manera, desde la mirada oficial, el espacio urbano en los años 80 aparecía como un potencial turístico para la economía de los grandes capitales, de acuerdo con José Villacrés, secretario del Quito Colonial, quien en 1981 disertó sobre el turismo en el centro de Quito. Sugestivo es el título de su artículo publicado en la prensa que resume su propuesta de la siguiente forma: "El casco colonial de Quito centro de interés turístico" ${ }^{27}$.

Por consiguiente, la Declaratoria deja a un lado, el legado aborigen del centro de la ciudad, desconociéndose "los núcleos de población indígena en el siglo XVI, [los mismos que] quedaron inscritos en la traza del Quito hispánico que tuvieron su antecedente inmediato en un asentamiento de matriz inca" 28.

Como se puede notar, esta exclusión constituye uno de los principales problemas del monumentalismo, pues la arquitectura y el patrimonio del CHQ es un lugar analítico donde se depositan diferentes formas de representar y delinear pensamientos sobre la nación, lo que le otorga el carácter múltiple. Así, resulta fecundo pensar el centro de la ciudad como plural, "pues en ese punto, que abarca 376 hectáreas, confluyen siglos de arte, de historias de libertad, de misticismo y sincretismo cultural" 29 .

Además, sus rastros históricos informan los orígenes diversos de la nación ecuatoriana como el colonial, aborigen y republicano. Y, actualmente, los procesos sociales donde la globalización de la cultura se convierte en un escenario que alimenta la identidad del país.

25. TERÁN NAJAS, Rosemarie, "Repensar el patrimonio: el caso del Centro Histórico de Quito", Revista del Patrimonio Cultural del Ecuador, n. 5 / I Semestre, 2014, pág. 16.

26. JIJÓN FRANCISCO, especialista en temas urbanos, entrevista por Raúl Zhingre, Quito, 29 de junio de 2015.

27. VILLACRES, José, "El casco colonial de Quito centro de interés turístico", Diario El Comercio (Quito), 20 de junio de 1981, pág. 1-D.

28. TERÁN NAJAS, Rosemarie, "Factores dinámicos del Desarrollo Urbano del Quito Colonial", Enfoques y estudios históricos. Quito a través de la historia, Quito, llustre Municipio de Quito, 1992, págs. 67-68.

29. Redacción Quito, "El patrimonio de Quito va más allá de los edificios", diario El Telégrafo, (Quito), 13 de septiembre de 2015. Recuperado de: http://www.eltelegrafo.com.ec/noticias/quito/11/el-patrimonio-de-quito-va-mas-alla-de-los-edificios (consultado el 11 de enero 2018). 


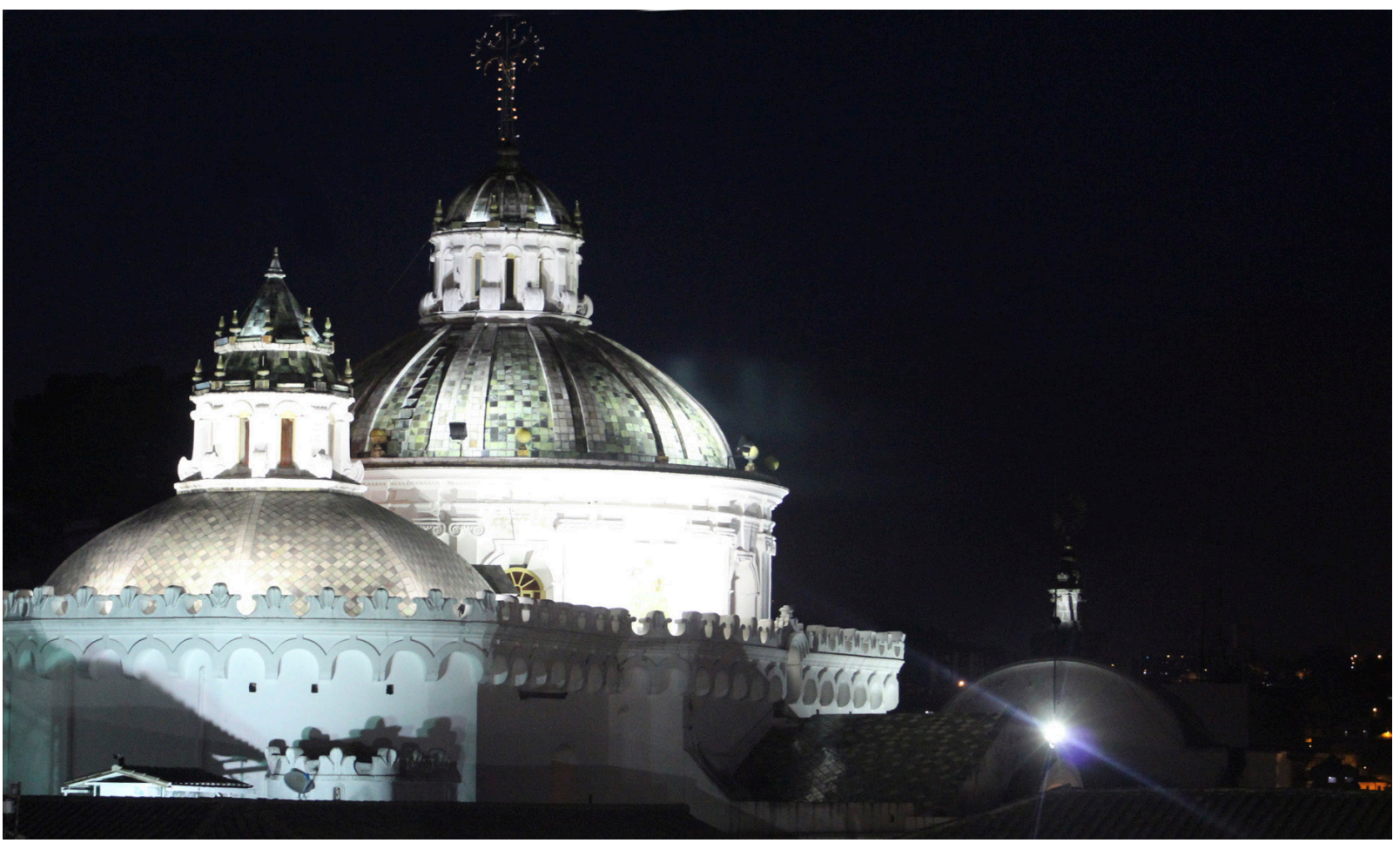

Fig. 4. Iglesia de la Compañía. Centro Histórico de Quito. Foto: Raúl Zhingre (Junio de 2017).

En esta necesidad de recrear el pasado y convertir algo en "patrimonio", el monumentalismo privilegió una ideologización del pasado colonial ${ }^{30}$. Para tal cometido, hizo uso del concepto "monumento histórico". Se pensaba que los monumentos eran aquellos que tenían un valor patrimonial, histórico o artístico en el que subyacía la historia de una nación. Mediante la producción de patrimonio, este enfoque asignaba valor a las estructuras monumentales y significaba el pasado desde el presente (años 80) privilegiando la nación de origen hispánico.

De acuerdo a lo anotado, esto fue posible porque el patrimonio como categoría "no es un vestigio neutral e inerte del pasado, sino un lugar desde el que se producen significados nuevos desde el presente". Además, el valor de los objetos patrimoniales no resulta de una autenticidad inherente sino atribuida: es construida por actores sociales como parte del proceso de reivindicar un lugar en la historia, generar una identidad y construir una genealogía legitimadora. Y con este criterio se destaca que el patrimonio no es una manifestación trasparente del pasado, sino una recreación politizada del mismo que, igual que la memoria, está siempre al servicio del presente ${ }^{31}$.

En suma, esta manera de observar el CHQ fue una entrada analítica venida de la oficialidad que se situó como herramienta de legitimación del poder a partir de una forma concreta de ver el pasado que

30. CARRIÓN MENA, Fernando, "Centro Histórico de Quito...", op. cit., pág. 25.

31. MUÑOZ ROJAS, Catalina, "Redefiniendo la memoria nacional: debates en torno a la conservación arquitectónica en Bogotá, 1930-1946", Revista Historia Crítica, n. ${ }^{\circ} 40,2010$. 
reivindica un espacio en el presente que, entre otros, benefició a la economía capitalista del turismo. De esto se desprende que las prácticas en torno al patrimonio son inevitablemente prácticas políticas o económicas, contrario a la aparente naturalidad y objetividad que revisten ${ }^{32}$.

El concepto monumento de uso común en los años 80 también hace referencia a una obra pública que se pone en memoria de un hecho importante, como testimonio y herencia que cobra importancia. As, el centro histórico como conjunto monumental es puesto en momería bajo la conservación como política central, convirtiéndolo en un componente inmutable y también único de la ciudad ${ }^{33}$.

Se puede acotar que en el marco de la coyuntura que se vivía en Ecuador, entre la dictadura militar de los años 70 y el retorno a la democracia de los años 80 , el monumentalismo careció de un proyecto de centro histórico con características nacionales que ayudara a consolidar al período de transición y así atender una serie de problemáticas sociales nacionales que se condensaron en el CHQ como la migración, la configuración del comercio informal, los problemas de movilidad y trasporte público, dotación de servicios básicos, etc.

Por ello, y debido al débil rol del Municipio de Quito para pensar el crecimiento de la ciudad, no bastó crear en 1978 el Instituto Nacional de Patrimonio Cultural para reemplazar a la Dirección de Patrimonio Artístico, menos aún emitir el Decreto de 1979 sobre la Ley de Patrimonio Cultural ni declarar en 1978 a Quito Patrimonio de la Humanidad. Tampoco fue suficiente que en 1984 se declarara a Quito como Bien perteneciente al Patrimonio Nacional, delegando su custodia a la Comisión del Centro Histórico de Quito ${ }^{34}$.

En relación con los decretos y leyes oficiales antes referidos, hay que subrayar que el monumentalismo como paradigma también se expresó en los planes urbanos, los cuales recogieron y reforzaron ese criterio. Es el caso del Plan Quito, que fue un conjunto de políticas urbanas diseñadas en la alcaldía de Álvaro Pérez, aprobado mediante ordenanza No. 2092, en 1981, que recomendó conservar el centro histórico mediante la Ordenanza 2342 de 1984, que siguió una línea similar a su antecesora, la Ordenanza 1727 de 1975 . El argumento central de la nueva Ordenanza radicaba en la mayor definición de las áreas de protección, como consecuencia de un excelente estudio sobre el territorio con varios niveles de valoración urbano-arquitectónica de todo el cantón Quito, que sirvió como importante referencia para estudios posteriores ${ }^{35}$.

Si bien la propuesta encerraba aspectos formales que incluían inventariar las zonas y estabilizar a la población del centro ${ }^{36}$, esta constituyó un precedente en el intento de conservar una parte trascendental de la ciudad que, sin embargo, "su redefinición no implicó, necesariamente, que la gestión local en cuanto al desarrollo urbano y la planificación tuvieran especial atención por el espacio patrimonial de los barrios periféricos" 37 .

\footnotetext{
32. Ibídem, pág. 5 .

33. CARRIÓN MENA, Fernando, El laberinto de las..., op. cit., pág. 68.

34. ORTIZ CRESPO, Alfonso, "La destrucción del centro histórico", Diario Hoy (Quito), 3 de enero de 1988, pág. 4-C.

35. CIFUENTES, Colón, "La regulación de las áreas patrimoniales en el proceso de planificación territorial de Quito", CARRIÓN MENA, Fernando (coord.), Quito: escenarios de innovación, Quito, OLACCHI/ Municipio Metropolitano de Quito, 2001, págs. 82-83.

36. Ibídem, pág. 81.

37. CABRERA HANNA, Jaime Santiago, "Monumentalismo, regeneración urbana, patrimonio y segregación social en las políticas de planificación de Quito (segunda mitad del siglo XX)", Concurso de ensayos 'La invención del Centro Histórico', Quito, 14 de abril de 2015, pág. 42.
} 
Del análisis del Plan Quito se puede pensar que este fue parte no solo de un discurso monumental sino también conservacionista que corresponde a las maneras de cómo las instituciones construyen el patrimonio y convierten al monumento en una cosa a conservar, en lugar de apreciarlo como un espacio de valores o significados culturales ${ }^{38}$. Por ello, este documento municipal no habló de la gestión patrimonial como política pública, que beneficiara a los barrios del CHQ, que se encontraban en extrema pobreza, sino que se basó en una comprensión fundamentalmente conservacionista y monumentalista.

En este sentido, El Plan Quito propugnó una organización de la ciudad y su centro histórico en el que tenía como principal preocupación lo urbano-arquitectónico, por lo tanto, privilegió los atributos de la monumentalidad. Para corroborar cuanto apuntamos reproducimos en seguida dos de sus objetivos sobre la ciudad y el centro. En cuanto a la ciudad se planteó: "propender a la conservación y preservación de las áreas históricas, conjuntos y monumentos". En cuanto al CHQ, se destaca una orientación monumental, al hablar en su eje general de la "definición de conjuntos monumentales al interior de las áreas del Centro" 39 . De ahí que el Plan Quito, no abordó al centro en su diversidad y complejidad ${ }^{40}$. Tampoco instituyó políticas de carácter social o de conservación en los barrios del centro, y atendió muy poco a las problemáticas sociales de los habitantes del área patrimonial ${ }^{41}$.

Para ilustrar las dificultades de la gestión municipal y la incapacidad para solucionar los problemas de pobreza de los barrios periféricos, basten algunos ejemplos. En un artículo de prensa de 1983 sobre el barrio El Placer, titulado "Vivienda en peligro y casi ningún servicio", se decía: “la vivienda está compuesta de 'mediaguas' y modestas casas ubicadas en la pendiente de la loma y carece de los servicios básicos elementales, estaban amenazados por los deslaves, no solo en épocas de invierno sino en verano también” ${ }^{42}$.

En el mismo año, el diario Últimas Noticias publicó una foto donde mostraba el drama humano del barrio San Juan. La gráfica ilustra la necesidad de vivienda de familias de escasos recursos, quienes habían levantado casuchas con el fin de solventar una necesidad vital ${ }^{43}$.

Por último, debe destacarse que producto del enfoque monumental, en el Plan Quito se aprecia una gran continuidad argumental, donde se bosqueja un análisis que silencia las dinámicas económicasproductivas, de desarrollo asociativo barrial, cultural y patrimonial que ayudaran a dar sentido y coherencia histórica a la ciudad, el CHQ y sus barrios, siendo esto, otro de los límites de este enfoque.

\section{La ciudad como diversidad, el Centro Histórico de Quito \\ y sus barrios analizados como una problemática social}

La acelerada dinámica de urbanización nacional y dado el contexto de crisis en que vivía el país llevó a que la problemática de la ciudad sea una necesidad inmediata a intervenir en los ańos 80 , lo que hizo de

\footnotetext{
38. SMITH, Laurajane, "El 'espejo patrimonial'...", op. cit., pág. 44.

39. Ilustre Municipio de Quito, Plan Quito, Quito, Ilustre Municipio de Quito, 1980, págs. 53, 533.

40. BUSTAMANTE, Gonzalo, "Población y medio ambiente: análisis de su relación", BONILLA, Efrén, Quito, trasformaciones urbanas y arquitectónicas, Serie Quito 9, Quito, Ilustre Municipio de Quito, 1994, pág. 53.

41. CORONEL CEVALLOS, Diego Giovanni, Impacto social de las políticas patrimoniales en el bulevar 24 de Mayo en Quito-Ecuador, Quito, tesis de maestría, Facultad Latinoamericana de Ciencias Sociales, Sede Ecuador, 2013, pág. 42.

42. "Vivienda en peligro y casi ningún servicio", Últimas Noticias (Quito), 3 de marzo de 1983, pág. 24.

43. "Dramas humanos", Últimas Noticias (Quito), 21 de septiembre de 1983, pág. 1.
} 


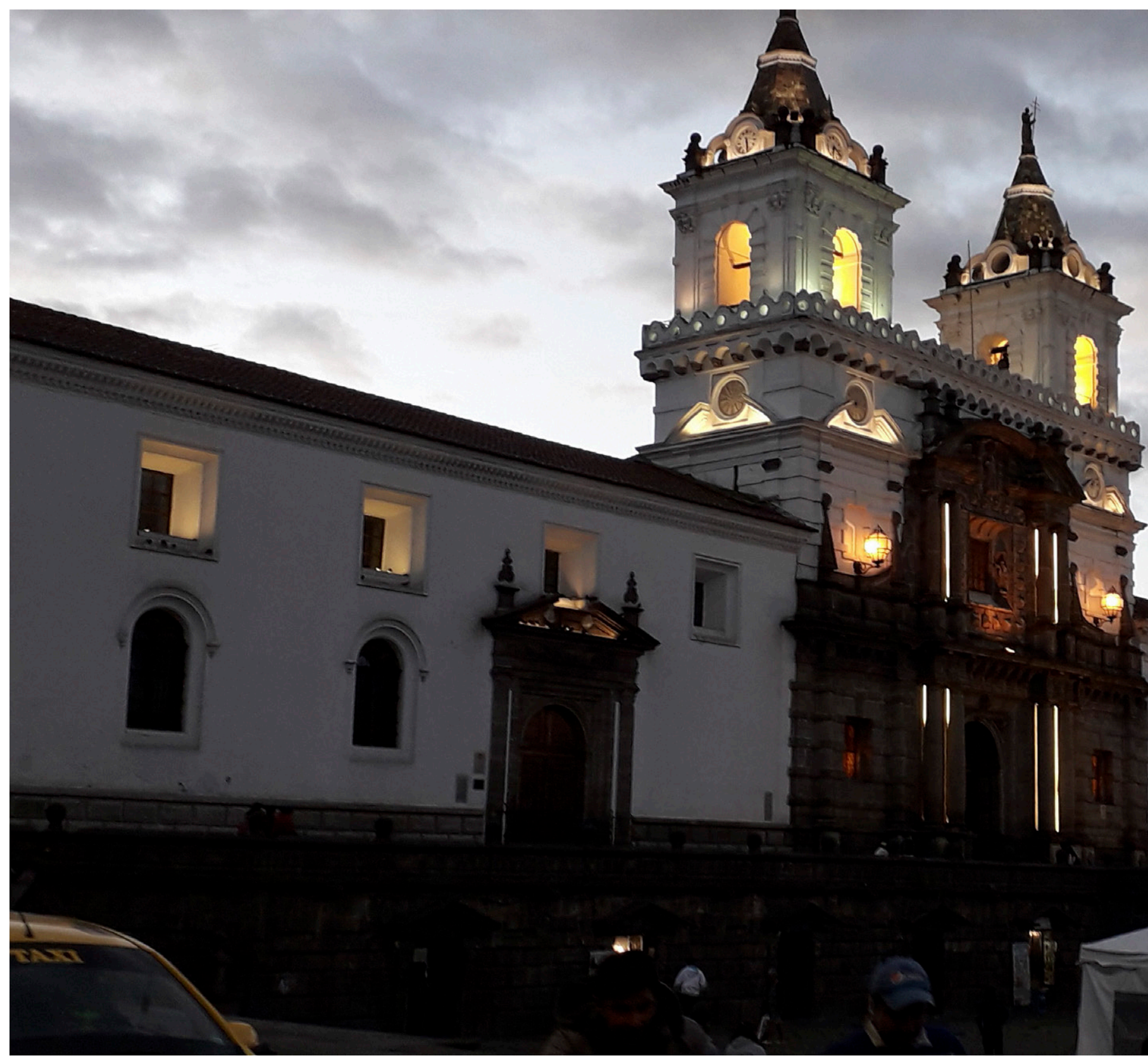

Fig. 5. Iglesia de San Francisco. Centro Histórico de Quito. Foto: Raúl Zhingre (Junio de 2017).

la investigación urbana una área de estudio coyuntural quizás más visiblemente ligada a la solución de los problemas que otras disciplinas. Es decir se privilegió las alternativas sobre el producto académico ${ }^{44}$.

Sin embargo, la propia dinámica de urbanización dejó poco tiempo para detenerse a reflexionar la ciudad como diversidad. Es a partir de 1988, y como parte del Plan Maestro, que iniciaron un conjunto de

44. CARRIÓN MENA, Fernando et al., "La investigación urbana en el Ecuador", CARRIÓN MENA, Fernando (ed.), La investigación urbana en América Latina, caminos recorridos y por recorrer, Quito, Estudios Nacionales, primera edición, 1989, pág. 159. 


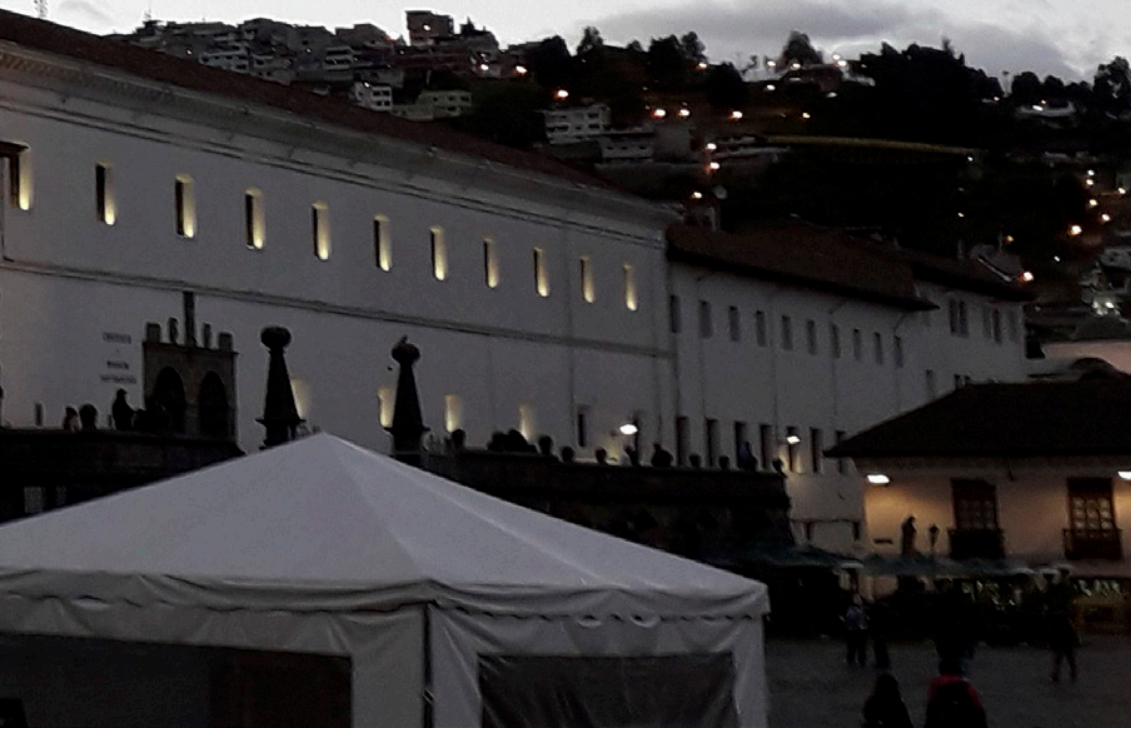

acumulaciones de sentidos críticos sobre lo urbano y el Municipio de Quito, producto de nuevos enfoques interpretativos, donde se integra el investigador en forma más directa a la problemática, lo que ayudó a comprender la ciudad y a definir la unidad de la ciudad, en lo económico, social y político, a partir de lo cual se inició el debate de la ciudad como diversidad y las distintas memorias de esta ${ }^{45}$.

Empero, no quiere decir que en los años 80 se haya llegado a estructurar una política de urbanización a nivel nacional, ni tampoco un desarrollo uniforme con características contestatarias, pues, a la par del enfoque de la ciudad como diversidad siguió existiendo, la visión monumental, funcional, utilitarista y técnica, apoyada por geógrafos, arquitectos, etc. Lo que se puede aseverar, sin embargo, es que al finalizar la década, Quito era la ciudad donde mayor nivel de investigación sobre temas urbanos había alcanzado.

En cuanto a discutir la ciudad en base a su diversidad, se dieron un cúmulo de experiencias investigativas, sobresalen trabajos como los de Kingman, quien habló de la ciudad como objeto histórico desde distintos enfoques, como la arquitectónica, recuentos historiográficos y otras que toman en cuenta las contradicciones del desarrollo urbano. Otros investigadores como Rosemary Terán discutieron la ciudad alrededor de la democratización del patrimonio histórico. Francisco Enríquez y Kleber Prias reflexionaron la economía urbana, mediante las dinámicas económicas informales en el CHQ. El mercado laboral urbano investigado por Gilda Farrel fue otro de los aportes de las reflexiones de la ciudad con base a su diversidad ${ }^{46}$.

45. KINGMAN GARCÉS, Eduardo, exdirector del Área de Historia del Plan Maestro, entrevista por Raúl Zhingre, Quito, 8 de junio de 2015.

46. KINGMAN GARCÉS, Eduardo, "Historia urbana: diversos enfoques", Enfoques y estudios históricos. Quito a través de la historia, serie n. ${ }^{\circ}$ Quito, Ilustre Municipio de Quito, 1992, pág. 17; TERÁN NAJAS, Rosemarie, "Factores dinámicos..." , op. cit., págs. 67-68; ENRÍQUEZ BERMEO Francisco, "La economía informal en el Centro Histórico", RAMOS GUERRA, Manuel (coord.), Centro Histórico de Quito, sociedad y espacio 
En atención a cómo definir la unidad de la ciudad, fue otro de los aportes del enfoque que reflexionó a la urbe como diversa, se delineó la noción de proceso en la interpretación de la urbanización de Quito, base desde la que nacerían muchas de las ideas del Plan Maestro, se identificó los escenarios de planificación posible para la ciudad como aquella que formuló, Fernando Carrión, en 1988, sobre el "derecho a la ciudad democrática", el mismo que estaba a tono con la propuesta de Quito como Distrito Metropolitano ${ }^{47}$.

Con el ánimo de superar las discusiones homogéneas monumentales, el Plan Maestro reflexionó sobre la ciudad conforme a su diversidad, y pretendió promover al CHQ como una problemática social más allá de la identidad colonial y urbano-arquitectónica. Con esto se buscaba superar aquellos paradigmas que veían en un sitio histórico no simples evidencias del pasado, sino que respondían a las necesidades sociales, políticas, económicas y culturales del presente que los establecía como tales para la reproducción de desigualdades ${ }^{48}$.

Un artículo publicado, en 1992 por Kingman, es representativo de la interpretación de la nación que abanderan los miembros del Plan Maestro y que suponía abandonar el énfasis en el pasado colonial en pro de una identidad de nación plural. En razón de lo expuesto, Kingman critica el enfoque arquitectónico porque ignoraba los factores sociales y culturales, así como aquellas narrativas de la historia nacional marcadas por nostalgias del pasado y una historicidad lineal en donde los conflictos urbanos eran silenciados ${ }^{49}$.

Por consiguiente, se propuso un centro histórico que no debía referirse exclusivamente a la herencia colonial como si esta fuera su única cualidad inherente, ni tampoco ser reducido a un espacio físico prefijado. Su definición implicó un reconocimiento de la presencia de una ciudad milenaria y, por extensión, de un centro multiétnico y pluritemporal, portador de procesos históricos contradictorios y conflictivos.

De ahí que contrario al monumentalismo, los investigadores del Plan Maestro plantearon la democratización en la comprensión patrimonial en el $\mathrm{CHQ}^{50}$. Esto porque según explica el Diario $E l$ Telégrafo, "la riqueza de Quito no solo está en su arquitectura, templos, conventos y plazas, sino también en su gente, en su gastronomía, en el lenguaje y en las actividades cotidianas de su población" 51.

Producto de estas reflexiones, en 1990 se incorporó la visión social de la rehabilitación y conservación de los bienes patrimoniales como elemento clave de gestión. Asimismo se incluyó la participación de la sociedad como actor en la sustentabilidad del patrimonio.

Además de estas consideraciones, al finalizar la década, los catorce barrios considerados periféricos del CHQ empezaron a ser tomados en cuenta en el conjunto de la estructura patrimonial. Estos fueron

urbano, Serie 2, Quito, Ilustre Municipio de Quito, 1990, págs. 63-88; PRIAS ORTEGA, Kleber, "Situación económica y desarrollo urbano", RAMOS GUERRA, Manuel (coord.), Centro histórico de Quito, sociedad y espacio urbano", Serie Quito 2, Quito, Ilustre Municipio de Quito, 1990; FARRELL, Gilda, "Los micro comerciantes del sector informal urbano: los casos de Quito y Guayaquil", CARBONETTO TORTONESSI, Daniel (coord.), El sector informal urbano en los países andinos, Quito, ILDIS, IIE-PUCE, 1985.

47. CARRIÓN MENA, Fernando; VALLEJO, René, "La planificación de Quito: del Plan Director a la ciudad democrática", CARRION MENA, Fernando, Quito, trasformaciones urbanas y arquitectónicas, serie 9, Quito, I. Municipio de Quito/ Junta de Andalucía, 1994.

48. MUÑOZ ROJAS, Catalina, "Redefiniendo...", op. cit., pág. 5.

49. KINGMAN GARCÉS, Eduardo, "Historia urbana: diversos enfoques...", op. cit., pág. 17.

50. CARRIÓN MENA, Fernando, "Centro Histórico de Quito...", op. cit., pág. 24; FRANCISCO JIJÓN, especialista en temas urbanos, entrevista por Raúl Zhingre, Quito, 29 de junio de 2015; TERÁN ROSEMARIE, historiadora, entrevista por Raúl Zhingre, Quito, 03 de junio de 2015.

51. Redacción Quito, "El patrimonio de Quito va más allá...", op. cit. 
analizados por los especialistas del Plan Maestro como un problema social y se inició una serie de reflexiones sobre vivienda, tugurización, transporte público, higiene, espacio público y sobre aquellas actividades que deterioraban el patrimonio, como las bodegas y la economía informal y popular ${ }^{52}$.

Son ilustrativos los ejemplos de estudios sobre las dinámicas económicas informales, los cuales muestran que el comercio informal no era una "lacra urbana" ni destruía, necesariamente, el patrimonio edificado, sino que formaba parte de un centro histórico diverso y complejo ${ }^{53}$, lo opuesto a la imagen que quería imprimir el enfoque monumental.

Era realmente una innovación el hecho de proponer estudios desde una pluralidad de discursos económicos, sociales y culturales sobre el centro y sus barrios, y transcender aquella perspectiva que consideraba a este espacio como lugar homogéneo de patrimonio monumental. Es en este contexto que la Agencia Española de Cooperación Internacional (AECI) y otros organismos internacionales comenzaron a trabajar y enriquecer el debate sobre la intervención en el CHQ, ofreciendo asistencia técnica y financiera para la rehabilitación de sus edificaciones ${ }^{54}$.

Esto es precisamente lo que se evidencia en el caso de los debates en torno a la Casa de los Siete Patios, como lo prueba el dato siguiente.

La AECI, en cooperación con el Municipio de Quito, de la alcaldía de Rodrigo Paz, enriqueció la perspectiva del CHQ como un lugar de vida, y abrió el debate sobre la ciudad histórica con la rehabilitación física y social del Centro, y el mejoramiento de las condiciones de vida de la población pobre que lo habita, mediante el caso de la Casa de los Siete Patios que introdujo la problemática social que, además, de la vivienda, incorporó, el tema del trabajo, la alimentación, la higiene, la participación comunitaria, el tugurio e inquilinato y su relación con la situación de los monumentos arquitectónicos ${ }^{55}$.

La Casa de los Siete Patios, ubicada en la calle Rocafuerte e Imbabura, en San Roque, una zona periférica por excelencia fue el ejemplo más dramático de deterioro económico, arquitectónico y social del CHQ, por cuanto estaba en juego la problemática del poblador. La intervención en la Casa saca a la luz los múltiples rostros de migrantes indígenas, campesinos y mendigos, y por ello, además de la restauración arquitectónica del inmueble, tenía como objetivo la preservación de los valores culturales y la memoria de quienes la habitaban, que eran memorias de historias de vidas calladas, que ocultaba la cotidianidad de los mismos, y que no era el resultado de una casualidad sino de un ocultamiento intencionado por el estigma que suponía el monumentalismo al calificarlos como sujetos "residuales" y que, a la vez, encontraron en la Casa la mejor forma de resistir a la pobreza ${ }^{56}$.

\footnotetext{
52. FRANCISCO JIJÓN, especialista en temas urbanos, entrevista por Raúl Zhingre, Quito, 29 de junio de 2015.

53. ENRÍQUEZ BERMEO, Francisco, "La economía informal...", op. cit., págs. 63-88; PRÍAS, K., "Situación económica y desarrollo urbano", Centro histórico de Quito, sociedad y espacio urbano, Serie Quito n. ${ }^{2}$ 2, Quito, I. Municipio de Quito, 1990, págs. $29-62$.

54. BUSTOS GUILLERMO, historiador, entrevista por Raúl Zhingre, Quito, 28 de junio de 2015.

55. CIFUENTES, Colón, arquitecto y experto en temas urbanos, entrevista escrita para Equipo Barrios, Proyecto de investigación "Dinámicas socio-espaciales, memoria histórica social y patrimonio cultural", Universidad Andina Simón Bolívar, Sede Ecuador, Instituto Metropolitano de Patrimonio, Quito, 1 de junio de 2015.

56. FRANCISCO JIJÓN, especialista en temas urbanos, entrevista por Raúl Zhingre, Quito, 29 de junio de 2015.
} 


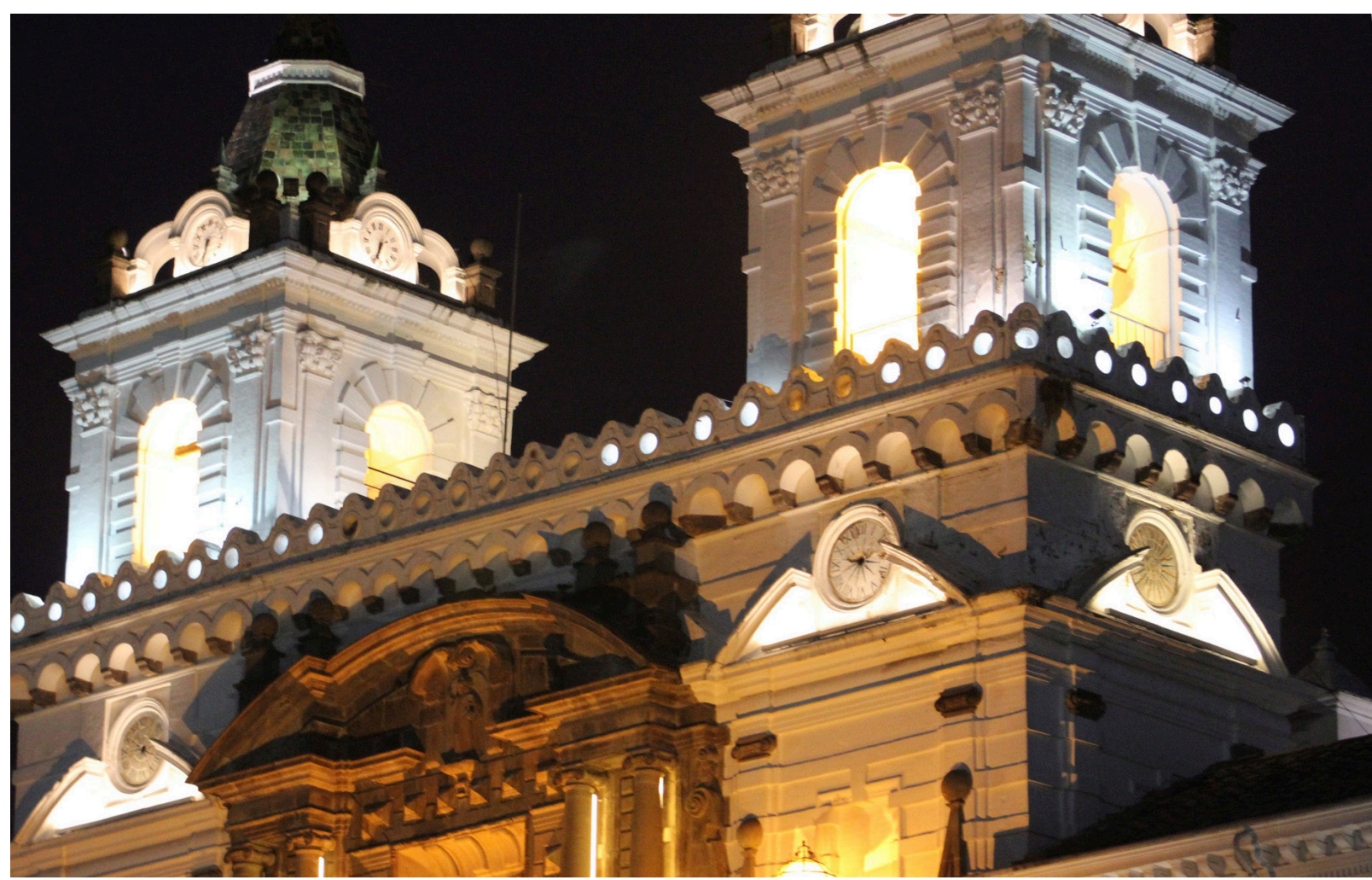

Fig. 6. Iglesia de San Francisco. Centro Histórico de Quito. Foto: Raúl Zhingre (Junio de 2017).

Toda vez que la AECI y el Municipio de Quito habían puesto el eje de la propuesta al CHQ y sus barrios como una problemática social, con el fin de captar la conciencia nacional, estas instituciones asumieron la importancia de disputar la reflexión de lo urbano en lo social. Bajo esta perspectiva el caso referido fue una propuesta presentada como una salida al problema de ausencia de política de gestión social, uso del espacio público como un sitio histórico y social, relocalización de los moradores del centro de la urbe, etc.

El proyecto arquitectónico estuvo a cargo del Arq. Handel Guayasamín de la oficina de Planificación del Municipio, y formaba parte del Plan del Distrito Metropolitano ${ }^{57}$. Fue presentado al conmemorarse el décimo aniversario de la Declaratoria de Quito como Patrimonio de la Humanidad, en 1988.

En este inmueble, se propuso, la adecuación de departamentos, compuesto por dos dormitorios y piezas individuales. La mayor parte de los servicios se decía deberían ser comunales, el comedor y la cocina estarán en manos de todos los moradores. También se planificó la instalación de una guardería, lavanderías, talleres artesanales, locales comerciales y una sala comunal. Además era un proyecto coyuntural que sirvió de modelo para otros planes para los años posteriores ${ }^{58}$.

57. CIFUENTES, Colón, "La Cooperación Española en el proceso de recuperación del Centro Histórico de Quito", PORRAS, María Elena y CALVO-SOTELO, Pedro (coords.), Ecuador- España. Historia y perspectiva, Quito, Embajada de España en el Ecuador, 2001, pág. 208.

58. "Una restauración para el pueblo", Diario Hoy (Quito), 17 de septiembre, 1988, pág. 8A. 
Finalmente, la construcción de la ciudad como un producto histórico y la búsqueda del pasado con un enfoque más amplio permitieron a esta perspectiva definir a la ciudad como escenario de la vida social y espacial, inscrita en un complejo de relaciones cambiantes en el tiempo. Todo esto, en el marco de la ciudad plural $^{59}$. Mostraron así, una realidad crítica al monumentalismo y evidenciaron, a la vez, cómo existen diversos imaginarios sobre el CHQ que han permanecido en disputa durante estos años, desarrollando una imagen de la ciudad conservada que transmite información sobre una determinada mirada sobre el patrimonio y la identidad nacional del Ecuador.

\section{Conclusiones}

El tema analizado en este trabajo, ha evidenciado al centro histórico como término polisémico, de registro múltiple, el entendimiento y caracterización navega en distintas apropiaciones. Por ejemplo, el Municipio anterior al terremoto de 1987, en el marco del paradigma monumental, concibe al Centro Histórico de Quito como homogéneo, arquitectónico, urbano, colonial y sin sujeto patrimonial, que privilegia, fundamentalmente, el comercio de grandes capitales y el turismo privado. En este sentido, el centro de la ciudad fue visto como recurso económico dirigido al turista para que admire la belleza y la estética del Centro. Además, se eleva como símbolo de la identidad nacional, recubierto de contenidos hispanistas.

Por otro lado, al finalizar la década, los especialistas del Plan Maestro proponen observar al CHQ como un lugar de vida y espacio vivo de alta dinámica, que significó un punto de quiebre en el entendimiento del centro de la ciudad como espacio plural en su identidad. El Centro de Quito fue analizado de forma cualitativa, se llegó a determinar que reflejaba una sociedad en movimiento, por ello, el escenario del Centro Histórico, se destacó por lo conflictivo y la desigualdad social, donde además era un polo de atracción para la ciudad de Quito, ligado a lo económico que resolvía necesidades de sobrevivencia para actores como los vendedores ambulantes, y, también escenario para el movimiento de grandes capitales.

\section{Bibliografía}

BALLART HERNÁNDEZ, Josep y I TRESSERAS, Jordi Juan, Gestión del patrimonio cultural, Barcelona, Planeta, 2010.

BUSTAMANTE, Gonzalo, "Población y medio ambiente: análisis de su relación”, BONILLA, Efrén, Quito, trasformaciones urbanas y arquitectónicas, Serie Quito 9, Quito, Ilustre Municipio de Quito, 1994, págs. 53-82. BUSTOS GUILLERMO, historiador, entrevista por Raúl Zhingre, Quito, 28 de junio de 2015.

CABRERA HANNA, Jaime Santiago, "El Centro Histórico de Quito en la planificación urbana (19421992). Discursos patrimoniales, cambios espaciales y desplazamientos socioculturales”, Territorios, n. ${ }^{\circ} 36$, 2017, págs. 189-215.

CABRERA HANNA, Jaime Santiago, "Los orígenes del discurso patrimonial autorizado en la planificación urbana de Quito", Simposio de Historia Urbana, IX Congreso Ecuatoriano de Historia 2015, Quito, 15 de julio de 2015.

59. CARRIÓN MENA, Fernando, "Prólogo", PERALTA, Evelia; GONZÁLEZ TAMARIT, Luis; CARRIÓN MENA, Fernando y ROMÁN RUÍZ, José (coords.), Centro Histórico de Quito, problemas y perspectivas, Serie Quito 1, Quito, llustre Municipio de Quito, 1990, pág. 11. 
CABRERA HANNA, Jaime Santiago, "Monumentalismo, regeneración urbana, patrimonio y segregación social en las políticas de planificación de Quito (segunda mitad del siglo XX)", VV. AA., Concurso de ensayos 'La invención del Centro Histórico', Quito, 2015, págs. 1-45.

CABRERA HANNA, Jaime Santiago, Propuesta Investigación sobre dinámicas socio espaciales, memoria socio histórica y patrimonio cultural, Centro Histórico y parroquias del DMQ, (presentado al Instituto de Patrimonio de Patrimonio- IMP), Quito, documento inédito, 2015.

CARRIÓN MENA, Fernando, "Centro Histórico de Quito: notas para el desarrollo de una política urbana alternativa”, PERALTA, Evelia; GONZÁLEZTAMARIT, Luis; CARRIÓN MENA, Fernando y ROMÁN RUÍZ, José (coords.), Centro Histórico de Quito, problemas y perspectivas, Serie Quito 1, Quito, Ilustre Municipio de Quito, 1990, págs. 15-38.

CARRIÓN MENA, Fernando, El laberinto de las centralidades históricas en América Latina: el centro histórico como objeto del deseo, Quito, Ministerio de Cultura del Ecuador, 2010.

CARRIÓN MENA, Fernando, "Prólogo", PERALTA, Evelia; GONZÁLEZ TAMARIT, Luis; CARRIÓN MENA, Fernando y ROMÁN RUÍZ, José (coords.), Centro Histórico de Quito, problemas y perspectivas, Serie Quito 1, Quito, Ilustre Municipio de Quito, 1990, págs. 11-12.

CARRIÓN MENA, Fernando y VALLEJO, René, "La planificación de Quito: del Plan Director a la ciudad democrática”, CARRION MENA, Fernando, Quito, trasformaciones urbanas y arquitectónicas, serie 9, Quito, I. Municipio de Quito/ Junta de Andalucía, 1994, págs. 143-169.

CARRIÓN MENA, Fernando et al., "La investigación urbana en el Ecuador", CARRIÓN MENA, Fernando (ed.), La investigación urbana en América Latina, caminos recorridos y por recorrer. Quito, Estudios nacionales, Primera edición, 1989, págs. 151-180.

CIFUENTES, Colón, "La Cooperación Española en el proceso de recuperación del Centro Histórico de Quito”, PORRAS, María Elena y CALVO-SOTELO, Pedro (coords.), Ecuador- España. Historia y perspectiva, Quito, Embajada de España en el Ecuador, 2001, págs. 208-213.

CIFUENTES, Colón, "La regulación de las áreas patrimoniales en el proceso de planificación territorial de Quito", CARRIÓN MENA, Fernando (coord.), Quito: escenarios de innovación, Quito, OLACCHI/ Municipio Metropolitano de Quito, 2001, págs. 63-105.

CORONEL CEVALLOS, Diego Giovanni, Impacto social de las politicas patrimoniales en el bulevar 24 de Mayo en Quito-Ecuador, Quito, tesis de maestría, Facultad Latinoamericana de Ciencias Sociales, Sede Ecuador, 2013.

ENRÍQUEZ BERMEO, Francisco, "La economía informal en el Centro Histórico", RAMOS GUERRA, Manuel (coord.), Centro Histórico de Quito, sociedad y espacio urbano, Serie 2, Quito, Ilustre. Municipio de Quito, 1990, págs. 63-89.

FARRELL, Gilda, "Los micro comerciantes del sector informal urbano: los casos de Quito y Guayaquil", CARBONETTO TORTONESSI, Daniel (coord.), El sector informal urbano en los países andinos, Quito, ILDIS, IIE-PUCE, 1985, págs. 139-179.

Fundación Teatro Bolívar, “Teatro Bolívar desde su inauguración en 1933 ha sido escenario de producciones más emblemática del arte musical y teatral”, http://www.teatrobolivar.org/sobre.html, (consultado el 11 de enero de 2018).

Ilustre Municipio de Quito. Plan Quito, Quito, Ilustre Municipio de Quito, 1980.

JIJÓN FRANCISCO, especialista en temas urbanos, entrevista por Raúl Zhingre, Quito, 29 de junio de 2015. KINGMAN GARCÉS, Eduardo, "Historia urbana: diversos enfoques", Enfoques y estudios históricos. Quito a 
través de la historia, serie n. ${ }^{\circ}$ 6, Quito, Ilustre Municipio de Quito, 1992, págs. 15-26.

MUÑOZ ROJAS, Catalina, "Redefiniendo la memoria nacional: debates en torno a la conservación arquitectónica en Bogotá, 1930-1946”, Revista Historia Crítica, n. o 40, 2010, págs. 20-43.

ORTIZ CRESPO, Alfonso, “La conservación de los centros históricos: ¿una utopía?”, Diario Hoy (Quito), 17 de enero, 1988.

ORTIZ CRESPO, Alfonso, "La destrucción del centro histórico", Diario Hoy (Quito), 3 de enero de 1988.

PRIAS ORTEGA, Kleber, "Situación económica y desarrollo urbano”, RAMOS GUERRA, Manuel (coord.), Centro histórico de Quito, sociedad y espacio urbano”, Serie Quito 2, Quito, Ilustre Municipio de Quito, 1990.

Redacción Quito, "El patrimonio de Quito va más allá de los edificios", diario El Telégrafo (Quito), 13 de septiembre de 2015, http://www.eltelegrafo.com.ec/noticias/quito/11/el-patrimonio-de-quito-va-masalla-de-los-edificios, (consultado el 11 de enero 2018).

SMITH, Laurajane, "El 'espejo patrimonial' ¿Ilusión narcisista o reflexiones múltiples?, Revista Antípoda, n.o 12, 2011, págs. 39-63.

TERÁN NAJAS, Rosemarie, "Factores dinámicos del Desarrollo Urbano del Quito Colonial”, Enfoques y estudios históricos. Quito a través de la historia, Quito, Ilustre Municipio de Quito, 1992, págs. 67-86.

TERÁN NAJAS, Rosemarie, "Repensar el patrimonio: el caso del Centro Histórico de Quito", Revista del Patrimonio Cultural del Ecuador, n. ${ }^{\circ}$ 5/ I Semestre, 2014, págs. 10-17.

TERÁN ROSEMARIE, historiadora, entrevista por Raúl Zhingre, Quito, 03 de junio de 2015.

VILLACRES, José, "El casco colonial de Quito centro de interés turístico", Diario El Comercio (Quito), 20 de junio de 1981.

VILLASÍS, Carlos, "Declaratoria de Quito”, Declarar el Centro Histórico de la ciudad de Quito "Patrimonio cultural del Estado”, Instituto de Patrimonio Cultural del Ecuador, Quito, diciembre de 1984. 